\title{
Immunotoxicological Investigation of 1-furan-2-yl-3-pyridin-2-yl-propenone in Female BALB/c Mice
}

\author{
Tae Won Jeon ${ }^{1}$, Chun Hwa Kım ${ }^{1}$, Sang Kyu LeE ${ }^{1}$, Gyu Sub Ko ${ }^{1}$, \\ Jin Woo Yoo ${ }^{1}$, Hyun Woo $\mathrm{HA}^{1}$, Wonku KANG ${ }^{2}$, Hye Gwang JeONG ${ }^{3}$, \\ Mi Jeong KANG ${ }^{1}$, Eung Seok LeE ${ }^{1}$, and Tae Cheon JeONG ${ }^{1}$,* \\ College of Pharmacy, ' Yeungnam University, Gyeongsan 712-749, ${ }^{2}$ Catholic University of Daegu, Gyeongsan 712-702, \\ ${ }^{3}$ Chungnam National University, Daejeon 305-764, Republic of Korea
}

(Received September 8, 2009; Revised September 30, 2009; Accepted September 30, 2009)

\begin{abstract}
Furan-2-yl-3-pyridin-2-yl-propenone (FPP-3) has recently been synthesized and characterized to have an anti-inflammatory activity through the inhibition of the production of nitric oxide and tumor necrosis factor- $\alpha$. In the present study, adverse effects of FPP-3 on immune functions were determined in female BALB/c mice. When mice were administered orally with FPP-3 at 125, 250 or $500 \mathrm{mg} / \mathrm{kg}$ for 7 consecutive days, FPP-3 suppressed the number of antibody-forming cells and reduced thymus weight at $500 \mathrm{mg} / \mathrm{kg}$. In addition, FPP-3 administered mice exhibited reduced splenic cellularity and numbers of splenocyte subsets, such as $\mathrm{CD}^{+}{ }^{+}$cells, $\mathrm{CD}^{+}{ }^{+} \mathrm{CD} 4^{+}$cells, $\mathrm{CD}^{+}{ }^{+} \mathrm{CD} 8^{+}$cells and macrophages. IL-4 mRNA expression was significantly suppressed by FPP-3 treatment. Moreover, the number of CD4 ${ }^{+} \mathrm{IL}-4^{+}$cells was reduced following the treatment of mice with $500 \mathrm{mg} / \mathrm{kg}$ of FPP-3. These results suggested that FPP-3 at $500 \mathrm{mg} / \mathrm{kg} \mathrm{might} \mathrm{be}$ immunotoxic, and that FPP-3-induced immunotoxicity might be mediated, at least in part, through the inhibition of cytokine production, such as IL-4.
\end{abstract}

Keywords: 1-Furan-2-yl-3-pyridin-2-yl-propenone, Immunotoxicity, Antibody-forming cells, Cytokines

\section{INTRODUCTION}

1-Furan-2-yl-3-pyridin-2-yl-propenone (FPP-3) is a chemically synthesized novel compound with a propenone moiety (Fig. 1). A recent study demonstrated that FPP-3 could inhibit lipopolysaccharide (LPS)-stimulated production of nitric oxide (NO) and tumor necrosis factor (TNF)- $\alpha$ in the cultures of RAW 264.7 macrophages in vitro (Lee et al., 2004). In addition, FPP-3 could not only inhibit cyclooxygenases (COXs) and 5-lipoxygenase activities but also inhibit COX-2 by 35 -times more selectively than COX-1 (Jahng et al., 2004). These results indicated that FPP-3 might have a potent anti-inflammatory activity. Therefore, further toxicological investigations for the development of FPP-3 as an anti-inflammatory drug were essential. Particularly, its immunotoxic potential would be critical, because FPP-3 affects immune systems for its pharmacological action.

*Corresponding author

Tel: +82-53-810-2819 Fax: +82-53-810-4654

E-mail: teacheon@ynu.ac.kr
In our previous study of hepatotoxicity evaluation, FPP-3 was hepatotoxic at a very high dose (Jeon et al., 2009). To our knowledge, however, toxicological effects of FPP-3 on immune functions in mice have not been reported yet. Thus, this study was conducted for the first time to examine whether exposure to FPP-3 has the potential to adversely affect immune functions. To evaluate the immunotoxic effects of FPP-3, we have chosen some parameters. For examples, the weights of body and lymphoid organs, such as spleen and thymus, antibody response to sheep

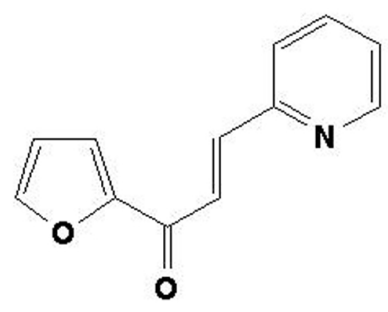

M.W., 199.21

Fig. 1. Structure of FPP-3 used for this study. 
red blood cells (SRBCs), spleen cellularity (nucleated cells), quantitation of the numbers of splenic B-cells, T-cells and macrophages, and lymphoproliferation by LPS or concanavalin $A$ (Con A) were determined. In addition, to elucidate the mechanism(s) of FPP-3-induced immunotoxicity, the in vivo effects of FPP-3 on the expressions of cytokine mRNA and/or the ability of spleen cells to produce intracellular cytokines, such as IL-2 and IL-4, were measured.

\section{MATERIALS AND METHODS}

\section{Animals}

Specific pathogen-free female BALB/c mice were obtained from the Orient (Seoul, Korea). The mice were received at 4-5 weeks of age and were acclimated for at least 2 weeks. Upon arrival, the animals were randomized and housed five per cage. All animals were maintained with gamma-irradiated LabDiet ${ }^{\mathbb{R}}$ (Purina Mills, MO) and tap water ad libitum. Mice of 6-7 weeks old $(20 \pm 2 \mathrm{~g})$ were used in the present study. The animal quarters were strictly maintained at $23 \pm 3^{\circ} \mathrm{C}$ and $50 \pm 10 \%$ relative humidity. $A$ 12-hr light/dark cycle was used with an intensity of 150-300 Lux.

\section{Materials}

FPP-3 (purity, >99\%) used in this study was chemically synthesized in our group (Jahng et al., 2004; Lee et al., 2004). Alserver's solution, DEAE-dextran, agar and corn oil were obtained from Sigma Chemical Company (St. Louis, MO). 2-Mercaptoethanol (2-ME), LPS, Con A, fetal bovine serum (FBS), Earle's balanced salt solution (EBSS), guinea pig complement, L-glutamine, penicillin G-streptomycin solution, and RPMI 1640 media were purchased from GIBCO (Grand Island, NY). CellTiter $96^{\mathbb{R}}$ AQueous Non-Radioactive Cell Proliferation Assay kit was purchased from Promega (Madison, WI). BD Cytofix/Cytoperm Plus ${ }^{\top \mathrm{M}}$ (with GolgiPlug ${ }^{\mathrm{TM}}$ ) kit was obtained from BD Biosciences (San Diego, CA). All antibodies used for the flow cytometry were purchased from Pharmingen (San Diego, CA). SRBCs were obtained from the College of Animal Sciences at Yeungnam University. All other chemicals used were of reagent grade commercially available.

\section{Animal treatment}

For the antibody response to SRBCs, mice were treated orally with FPP-3 at 125,250 or $500 \mathrm{mg} / \mathrm{kg}$ in $10 \mathrm{ml}$ corn oil once daily for 7 consecutive days. FPP-3 exposed mice were immunized intraperitoneally with $5 \times 10^{8} \mathrm{SRBCs}$ per mouse in $0.5 \mathrm{ml}$ of EBSS 4 days prior to enumerating the numbers of antibody-forming cells (AFC). In a subsequent study, mice were administered with the same doses of FPP-3 without an immunization, followed by the assays for splenic lymphocyte phenotyping, reverse transcriptionpolymerase chain reaction (RT-PCR), intracellular interleukins (ILs) production, and ex vivo mitogen-stimulated proliferation. The control animals received corn oil only at $10 \mathrm{ml} / \mathrm{kg}$. All animal care and procedures were conducted according to the Guiding Principles in the Use of Animals in Toxicology, as adopted by the Society of Toxicology (Reston, VA) in 1989 and Yeungnam University.

\section{Splenic antibody response to the T-dependent antigen, SRBCs}

On the day of necropsy, spleens were removed and weighed. Single cell suspensions were prepared in $3 \mathrm{ml}$ of EBSS, washed and resuspended in $3 \mathrm{ml}$ of EBSS. Spleen cells were then diluted 30 -fold by resuspending a $100 \mu \mathrm{l}$ aliquot of each suspension in $2.9 \mathrm{ml}$ of EBSS. The number of AFC was determined using a modified hemolytic Jerne plaque assay (Kaminski et al., 1990). The results were expressed as $\mathrm{AFC} / 10^{6}$ spleen cells and $\mathrm{AFC} /$ spleen.

\section{Quantitation of splenic and thymic lymphocyte subpo- pulations}

The lymphocyte subpopulations in spleen and thymus were quantitated using a modified method of Jeon et al. (2005). To enumerate B-cells, T-cells, $\mathrm{CD}^{+}$and $\mathrm{CD} 8^{+}$ T-cell subsets, and macrophages, splenic and thymic cells were collected and suspended in a staining buffer containing $2 \%$ FBS and $0.1 \%$ sodium azide in phosphate-buffered saline (PBS), $\mathrm{pH} 7.4$, to a cell density of $1.0 \times 10^{6} /$ tube. The cells were incubated with anti-mouse CD16/CD32 Fc receptor $(1 \mu \mathrm{g} /$ tube, clone $2.4 \mathrm{G} 2$, Pharmingen, San Diego, $\mathrm{CA}$ ) for $15 \mathrm{~min}$ at $4^{\circ} \mathrm{C}$ to prevent nonspecific binding and then labeled with an appropriate monoclonal antibody $(\mathrm{mAb})$ conjugated to a fluorescent probe. For spleen cells, anti-mouse $\mathrm{CD} 3 \mathrm{e}$ mAb (clone, 145-2C11) conjugated to peridinin chlorophyll-a protein was used to enumerate T-cells. For T-cell subsets, in spleen and thymus, fluorescein isothiocyanate (FITC)-conjugated anti-mouse CD4 (clone, GK1.5) and phycoerythrin (PE)-conjugated anti-mouse CD8a (clone, 53-6.7) were used. B-cells and macrophages were stained with anti-mouse CD45R/B220 $\mathrm{mAb}$ (clone, RA3-6B2) conjugated to PE and FITC-conjugated anti-mouse CD11b (clone, M1/70), respectively. An isotype control was used for each antibody. Cell suspensions were incubated with appropriate antibodies at 1 $\mu \mathrm{g} /$ tube for at least $30 \mathrm{~min}$ on ice in the dark. After incubation, the 1× FACS Lysing solution (Becton Dickinson, 
San Jose, CA) was treated for $10 \mathrm{~min}$ for hemolysis of erythrocyte. The cells were washed twice, resuspended in PBS containing $2 \%$ FBS and $0.1 \%$ sodium azide in total volume of $0.5 \mathrm{ml}$, and analyzed using a FACSCalibur ${ }^{\circledR}$ flow cytometry with CellQuest ${ }^{\mathbb{R}}$ software (Becton Dickinson).

\section{Mitogen-induced lymphocyte proliferation assay}

Effects of FPP-3 on ex vivo lymphoproliferative responses in splenocyte cultures isolated from the mice exposed to FPP-3 for 7 consecutive days were determined. Spleen cell suspensions from FPP-3-treated mice were prepared in EBSS, washed and resuspended in RPMI 1640 medium containing 5\% FBS, $2 \mathrm{mM} \mathrm{L-glutamine,} 100 \mathrm{U} / \mathrm{ml}$ penicillin, $100 \mu \mathrm{g} / \mathrm{ml}$ streptomycin and $50 \mu \mathrm{M} 2-\mathrm{ME}$. The cell number was adjusted to $1.11 \times 10^{6} \mathrm{cell} / \mathrm{s} / \mathrm{ml}$ of culture media. Then the cell suspension $(180 \mu \mathrm{l})$ was transferred to each well of a 96-well tissue culture plate (Costar). The cultures were incubated in a humidified $5 \% \mathrm{CO}_{2}$ incubator at $37^{\circ} \mathrm{C}$ in the presence of given concentrations $(20 \mu \mathrm{l})$ of either LPS (10 $\mu \mathrm{g} / \mathrm{ml})$ or Con A $(2 \mu \mathrm{g} / \mathrm{ml})$ for $72 \mathrm{hr}$. After incubation, $20 \mu \mathrm{l}$ of CellTiter $96^{\circledR}$ AQueous Non-Radioactive Cell Proliferation kit was added in each well, and then the plate was incubated in the incubator for additional $4 \mathrm{hr}$. The plate was read on a micro ELISA reader (TECAN A-5082, Austria) at a wavelength of $490 \mathrm{~nm}$. Results were expressed as mean absorbance minus naive control's absorbance.

\section{RNA preparation and mRNA analysis by RT-PCR}

For in vitro activation, single cell suspensions $\left(2.5 \times 10^{6}\right.$ splenocytes $/ \mathrm{ml}$ ) from mice administered with FPP-3 were cultured with $2 \mu \mathrm{g} / \mathrm{ml}$ of Con A in the presence of recombinant IL-2 (rlL-2, Roche Applied Science, Mannheim, Germany) at $37^{\circ} \mathrm{C}$ in $5 \% \mathrm{CO}_{2}$ for $24 \mathrm{hr}$. Following incubation, total RNA was prepared using RNAzol ${ }^{\mathrm{TM}} \mathrm{B}$ reagent (Tel-Test, Inc.). First-strand cDNA was prepared from $2 \mu \mathrm{g}$ of total RNA in $20 \mu \mathrm{l}$ with oligo (dT) 18 using the First Strand cDNA Synthesis Kit (Fermentas Inc.). PCR was performed with $4 \mu \mathrm{l}$ of the generated cDNA using 0.5 $\mathrm{U}$ of Taq polymerases (Solgent Inc., Korea). The following primer pairs were purchased from Solgent. The sense and anti-sense primer sequences used were: IL-2, 5'-GTGCTCCTTGTCAACAGCGC-3', 5'- GAGCCTTATGTGTTGTAAGC-3'; IL-4, 5'-ACAAAAATCA CTTGAGAGAGATCAT-3', 5'-AGTAATCCATTTGCATGATGCT CTT-3'; and $\beta$-actin, 5'-CAGGTCCCGGCCAGCCAGGT- 3', 5'-CACCCGCCACCA GTTCGCCA-3'. PCR was performed using the TGRADIENT (Biometra, Germany). The denaturation, annealing, extension, and cycle conditions were as follows: IL-2, $94^{\circ} \mathrm{C}$ for $30 \mathrm{~s}, 58^{\circ} \mathrm{C}$ for $30 \mathrm{~s}, 72^{\circ} \mathrm{C}$ for $30 \mathrm{~s}$ and $35 \mathrm{cy}-$ cles; IL-4, $94^{\circ} \mathrm{C}$ for $30 \mathrm{~s}, 60^{\circ} \mathrm{C}$ for $30 \mathrm{~s}, 72^{\circ} \mathrm{C}$ for $30 \mathrm{~s}$ and 40 cycles; $\beta$-actin, $94^{\circ} \mathrm{C}$ for $30 \mathrm{~s}, 63^{\circ} \mathrm{C}$ for $30 \mathrm{~s}, 72^{\circ} \mathrm{C}$ for $30 \mathrm{~s}$ and 25 cycles. The PCR products were electrophoresed through a $1.5 \%$ agarose gel and visualized by ethidium bromide staining and UV irradiation. The gel images were captured on an Image Analysis System (SLB, Seoul, Korea) and the PCR product yields were normalized to $\beta$-actin after a quantitative estimation using Labworks software (UVP, Inc., Upland, CA). Prior to analysis, the band intensities of PCR products were checked to ensure that they had not reached the saturation intensity.

\section{Determination of intracellular IL-2 and IL-4 production}

For in vitro activation, single cell suspensions $\left(1 \times 10^{6}\right.$ splenocytes $/ \mathrm{ml}$ ) from mice administered with FPP-3 were cultured with $2 \mu \mathrm{g} / \mathrm{ml}$ of Con A in the presence of recombinant IL-2 (rlL-2, Roche Applied Science, Mannheim, Germany) at $37^{\circ} \mathrm{C}$ in $5 \% \mathrm{CO}_{2}$ for $12 \mathrm{hr}$. After incubation, the splenocytes were stimulated again with the rlL-2 and Con A for $5 \mathrm{hr}$. Brefeldin A (10 $\mu \mathrm{g} / 10^{6}$ cells) was added in this stage. Then the cells were washed with staining buffer, and blocked nonspecific binding through adding anti-mouse CD16/CD32 Fc receptor $\left(1 \mu \mathrm{g} / 10^{6}\right.$ cells/tube) for 20 min on ice. The CD4 ${ }^{+}$cells were identified using FITCconjugated anti-mouse CD4 (0.5 $\mu \mathrm{g} /$ tube; clone, GK1.5) $\mathrm{mAb}$, which was suspended in staining buffer and incubated for 30 min on ice in a dark condition. To simplify the fixation and permeabilization of cells for immunofluorescent staining of intracytoplasmic ILs, the BD Cytofix/ Cytoperm Plus $^{\mathrm{TM}}$ (with GolgiPlug ${ }^{\mathrm{TM}}$ ) kit was used. To fix and permeabilize the cells, Cytofix/Cytoperm solution (100 $\mu /$ tube) was added and incubated on ice for $20 \mathrm{~min}$ at dark. And then, $1 \times$ Perm/Wash solution ( $1 \mathrm{ml} / \mathrm{tube})$ was added for washing. To stain intracellular cytokines, the fixed/permeabilized cells were incubated with $100 \mu \mathrm{l}$ of Perm/Wash solution containing PE-conjugated anti-mouse IL-2 mAb (0.25 $\mu \mathrm{g} /$ tube; clone, JES6-5H4) or IL-4 mAb $(0.25 \mu \mathrm{g} /$ tube; clone, 11B11) on ice for $30 \mathrm{~min}$ at dark. After washing with $1 \times$ Perm/Wash solution twice, the cells were resuspended in staining buffer ( $300 \mu \mathrm{l} /$ tube) and performed the flow cytometric analysis.

\section{Statistics}

The results were expressed as the mean \pm S.E. and the statistical differences between the different dose groups and the vehicle control were determined by one-way analysis of variance followed by the Dunnett's two tailed post-hoc test (SPSS program, ver. 10.0). The significant values at either $p<0.05\left(^{*}\right)$ or $p<0.01\left(^{* *}\right)$ were represented as asterisks. 
Table I. Effects of FPP-3 on weights of body and lymphoid organs in female BALB/c mice

\begin{tabular}{|c|c|c|c|c|c|}
\hline \multirow{2}{*}{ FPP-3 (mg/kg) } & \multirow{2}{*}{ Body weight (g) } & \multicolumn{2}{|c|}{ Absolute weights (mg) } & \multicolumn{2}{|c|}{ Relative weights ( $\%$ body weight) } \\
\hline & & Spleen & Thymus & Spleen & Thymus \\
\hline $\mathrm{VH}$ & $22.4 \pm 0.7$ & $141 \pm 6$ & $72 \pm 5$ & $0.63 \pm 0.02$ & $0.32 \pm 0.02$ \\
\hline 125 & $23.1 \pm 0.7$ & $167 \pm 11$ & $69 \pm 4$ & $0.72 \pm 0.03^{*}$ & $0.30 \pm 0.01$ \\
\hline 250 & $22.8 \pm 0.3$ & $152 \pm 6$ & $64 \pm 5$ & $0.67 \pm 0.02$ & $0.28 \pm 0.03$ \\
\hline 500 & $22.6 \pm 0.5$ & $145 \pm 7$ & $67 \pm 4$ & $0.65 \pm 0.03$ & $0.29 \pm 0.02$ \\
\hline
\end{tabular}

Female BALB/c mice were treated orally with FPP-3 in corn oil at $10 \mathrm{ml} / \mathrm{kg}$ for 7 consecutive days. Four days before necropsy, mice were immunized with SRBCs intraperitoneally. Each value represents mean \pm S.E. of 5 animals. The asterisks indicate the values significantly different from the vehicle control $(\mathrm{VH})$ at $p<0.05\left(^{*}\right)$.

Table II. Effects of FPP-3 without an immunization on weights of body and lymphoid organs in female BALB/c mice

\begin{tabular}{|c|c|c|c|c|c|}
\hline \multirow{2}{*}{ FPP-3 (mg/kg) } & \multirow{2}{*}{ Body weight (g) } & \multicolumn{2}{|c|}{ Absolute weights (mg) } & \multicolumn{2}{|c|}{ Relative weights (\% body weight) } \\
\hline & & Spleen & Thymus & Spleen & Thymus \\
\hline $\mathrm{VH}$ & $21.2 \pm 0.7$ & $96 \pm 6$ & $75 \pm 2$ & $0.45 \pm 0.02$ & $0.35 \pm 0.01$ \\
\hline 125 & $21.5 \pm 0.2$ & $105 \pm 2$ & $79 \pm 4$ & $0.49 \pm 0.01$ & $0.37 \pm 0.02$ \\
\hline 250 & $21.8 \pm 0.3$ & $100 \pm 5$ & $73 \pm 3$ & $0.46 \pm 0.02$ & $0.33 \pm 0.01$ \\
\hline 500 & $19.3 \pm 0.5$ & $88 \pm 8$ & $42 \pm 7^{* *}$ & $0.45 \pm 0.03$ & $0.22 \pm 0.03^{* *}$ \\
\hline
\end{tabular}

Female BALB/c mice were administered orally with FPP-3 in corn oil at $10 \mathrm{ml} / \mathrm{kg}$ for 7 consecutive days. The body and organ weights were on the day of necropsy. Each value represents mean \pm S.E. of 5 animals. The asterisks indicate the values significantly different from the vehicle control $(\mathrm{VH})$ at $\left.p<0.01{ }^{* *}\right)$.

\section{RESULTS}

Following that FPP-3 treated mice were sensitized intraperitoneally with SRBCs, the antibody response to SRBCs was enumerated four days later. Although the weights of body and lymphoid organs were not changed, FPP-3 at $500 \mathrm{mg} / \mathrm{kg}$ significantly decreased in the number of AFC in response to SRBCs by $25 \%$ when compared with the vehicle control (Table I and Fig. 2).

In the subsequent study, to determine the cellular target of FPP-3-induced immunotoxicity, mice were administered with the same doses of FPP-3 without an immunization, followed by splenic and thymic lymphocytes phenotyping using a flow cytometry. FPP-3 significantly decreased in the absolute and relative thymus weights by $44 \%$ and $37 \%$ at $500 \mathrm{mg} / \mathrm{kg}$ when compared to the vehicle control, respectively, but did not alter the spleen weight (Table II). In the flow cytometry, the mice treated with $500 \mathrm{mg} / \mathrm{kg}$ of FPP-3 showed a significant decrease in the \% of macrophages to total splenocytes (Table III). As shown in Fig. 3 and 4, FPP-3 significantly reduced the absolute numbers of splenocytes and thymocytes at $500 \mathrm{mg} / \mathrm{kg}$ by $26 \%$ and $74 \%$, respectively. FPP-3 significantly decreased in the numbers of total T-cells, $\mathrm{CD} 4^{+}$cells, $\mathrm{CD} 8^{+}$cells and macrophages in spleen at $500 \mathrm{mg} / \mathrm{kg}$. The $\%$ of $\mathrm{CD} 4^{+}$and $\mathrm{CD} 8^{+}$ T-cell subsets to total thymocytes were altered following the treatment with $500 \mathrm{mg} / \mathrm{kg}$ FPP-3 (Fig. 4A). The numbers of immature $\mathrm{CD} 4^{+} \mathrm{CD} 8^{+}$cells and $\mathrm{CD} 4^{+} \mathrm{CD} 8^{-}$cells

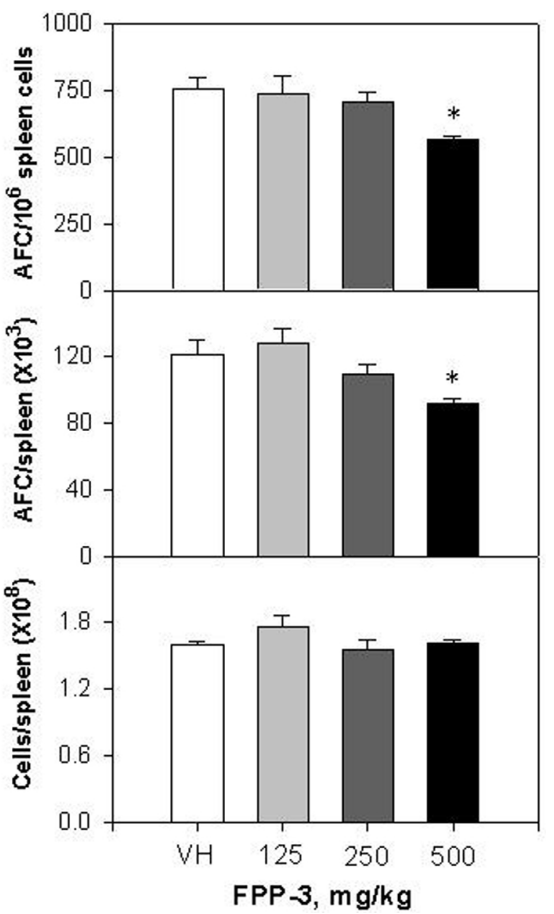

Fig. 2. Effect of FPP-3 on T-dependent antibody response in female BALB/c mice. Mice were treated orally with FPP-3 in corn oil at $10 \mathrm{ml} / \mathrm{kg}$ for 7 consecutive days. Four days before enumerating the numbers of antibody-forming cells (AFC), mice were immunized with SRBCs intraperitoneally. Each value represents the mean \pm S.E. of 5 animals. The asterisks indicate the values significantly different from the vehicle control $(\mathrm{VH})$ at $p<0.05\left(^{*}\right)$. 
Table III. Effects of FPP-3 without an immunization on phenotype percentage of splenocytes

\begin{tabular}{clrrrr}
\hline \multirow{2}{*}{ Phenotypes } & \multicolumn{4}{c}{ FPP-3 $(\mathrm{mg} / \mathrm{kg})$} \\
\cline { 2 - 5 } & \multicolumn{1}{c}{ VH } & 125 & \multicolumn{1}{c}{250} & 500 \\
\hline Spleen (\%) & T cells & $46.87 \pm 0.88$ & $46.11 \pm 0.70$ & $47.11 \pm 0.53$ & $47.78 \pm 1.66$ \\
& CD4 $^{+}$cells & $29.25 \pm 0.72$ & $27.09 \pm 0.51$ & $28.73 \pm 0.52$ & $28.73 \pm 2.00$ \\
& CD8 $^{+}$cells & $10.86 \pm 0.20$ & $9.79 \pm 0.25$ & $10.01 \pm 0.38$ & $10.37 \pm 0.43$ \\
B cells & $50.61 \pm 0.75$ & $50.57 \pm 0.94$ & $50.39 \pm 1.01$ & $53.01 \pm 2.01$ \\
& Macrophages & $3.73 \pm 0.30$ & $3.80 \pm 0.33$ & $4.09 \pm 0.25$ & $2.50 \pm 0.42^{*}$ \\
\hline CD4 $^{+} /$CD8 $^{+}$ & $2.70 \pm 0.11$ & $2.77 \pm 0.05$ & $2.89 \pm 0.17$ & $2.77 \pm 0.13$ \\
\hline
\end{tabular}

Mice were administered orally with FPP-3 in corn oil at $10 \mathrm{ml} / \mathrm{kg}$ for 7 consecutive days. Each bar represents the mean number of cells \pm S.E. of 5 animals. The asterisks indicate the values significantly different from the vehicle control $(\mathrm{VH})$ at $p<0.05\left(^{*}\right)$.

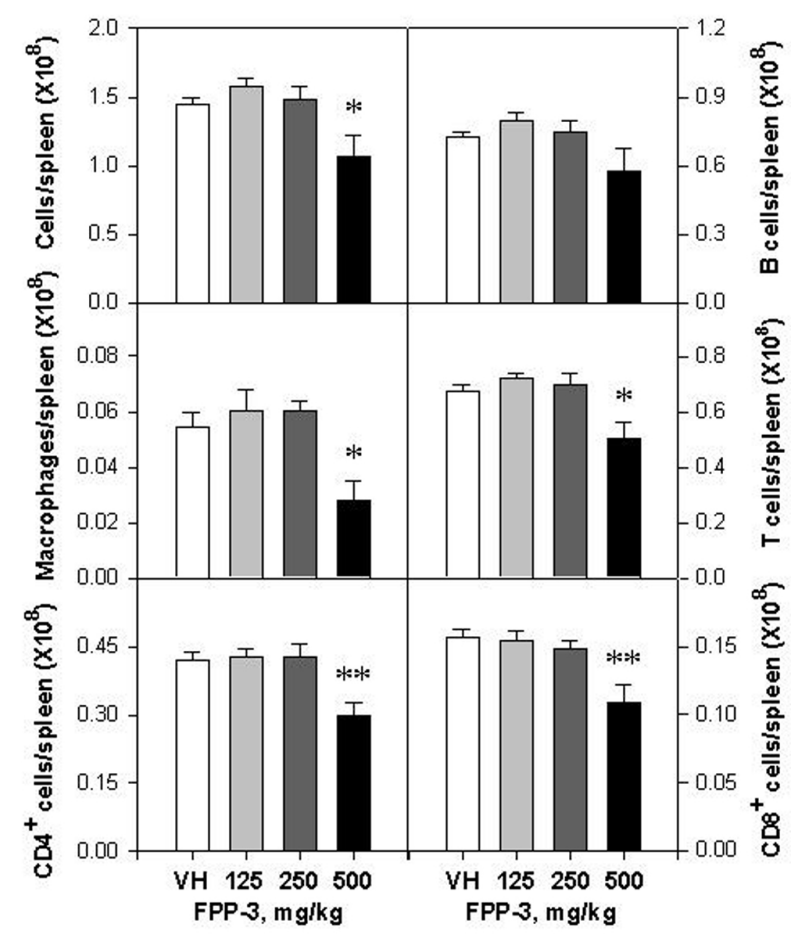

Fig. 3. Effect of FPP-3 on splenic lymphocyte subpopulations in female BALB/c mice. Mice were administered orally with FPP-3 in corn oil at $10 \mathrm{ml} / \mathrm{kg}$ for 7 consecutive days. Each bar represents the mean number of cells \pm S.E. of 5 animals. The asterisks indicate the values significantly different from the vehicle control $(\mathrm{VH})$ at either $p<0.05\left(^{*}\right)$ or $p<0.01\left(^{* *}\right)$.

in thymus were remarkably decreased at $500 \mathrm{mg} / \mathrm{kg}$ FPP-3, whereas CD4 ${ }^{-} \mathrm{CD} 8^{-}$cells were significantly increased at the same dose (Fig. 4B).

In the ex vivo mitogen-stimulated proliferation assay, splenocytes isolated from FPP-3 administered mice were cultured for $72 \mathrm{hr}$ in the presence of either bacterial LPS or Con A. As shown in Fig. 5, the FPP-3 at 125, 250 and 500 $\mathrm{mg} / \mathrm{kg}$ suppressed Con A-induced lymphoproliferation approximately $12 \%, 18 \%$ and $26 \%$ when compared with the vehicle control, respectively.
A

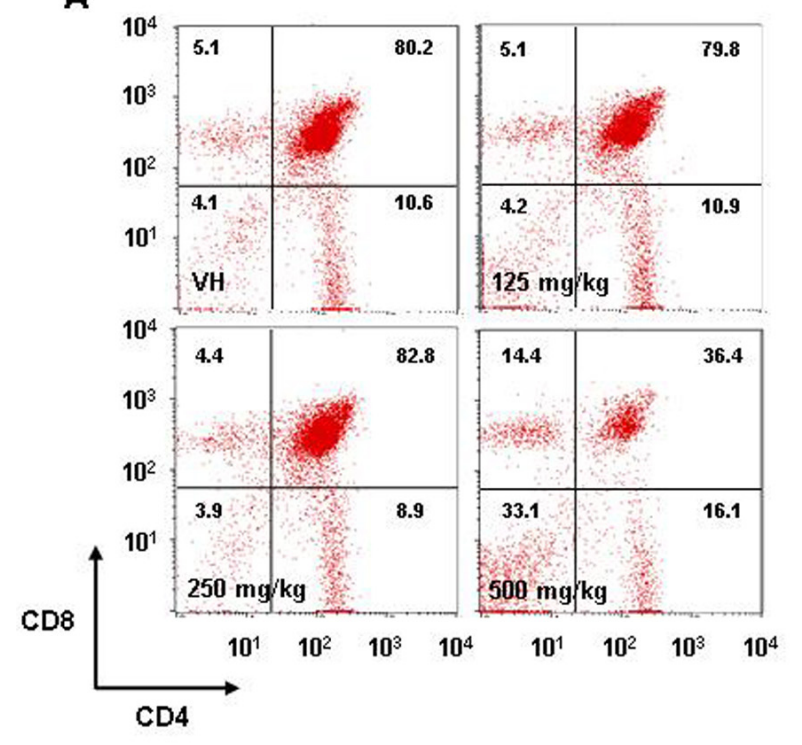

B

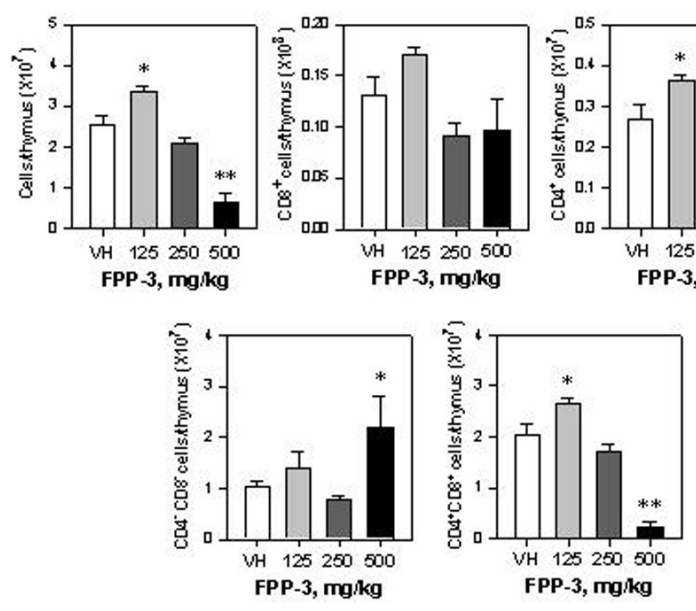

Fig. 4. Effect of FPP-3 on thymic lymphocyte subpopulations in female BALB/c mice. Mice were administered orally with FPP-3 in corn oil at $10 \mathrm{ml} / \mathrm{kg}$ for 7 consecutive days. (A) Percentage of thymocytes. (B) Absolute number of thymocytes. Each bar represents the mean number of cells \pm S.E. of 5 animals. The asterisks indicate the values significantly different from the vehicle control $(\mathrm{VH})$ at either $p<0.05\left(^{*}\right)$ or $p<0.01\left(^{* *}\right)$. 


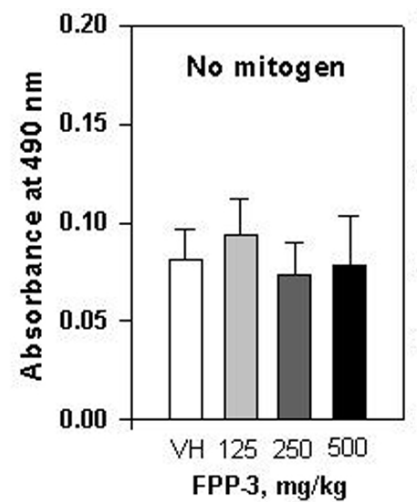

FPP_3, $\mathrm{mg} / \mathrm{kg}$

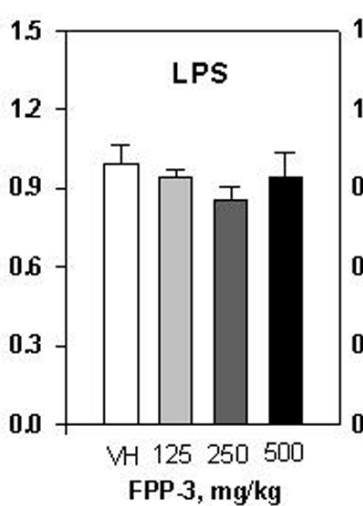

FPP $3, \mathbf{m g} / \mathbf{k g}$

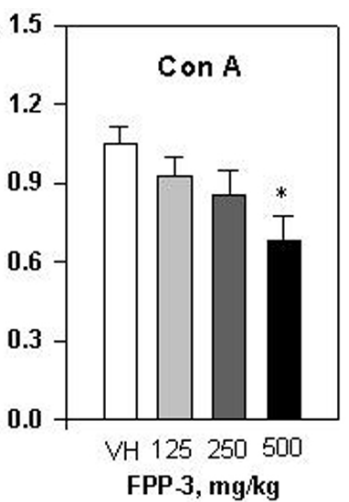

Fig. 5. Effect of FPP-3 on ex vivo lymphoproliferative responses in splenocyte cultures from female BALB/c mice. Splenocytes isolated from FPP-3 administered mice were cultured for $72 \mathrm{hr}$ in the presence of either bacterial lipopolysaccharide (LPS) or concanavalin A (Con A). Detailed conditions were described in the Materials and Methods. Each bar represents the mean absorbance at $490 \mathrm{~nm} /$ well \pm S.E. of 5 animals. The asterisks indicate the values significantly different from the vehicle control $(\mathrm{VH})$ at $p<0.05\left(^{*}\right)$.
A

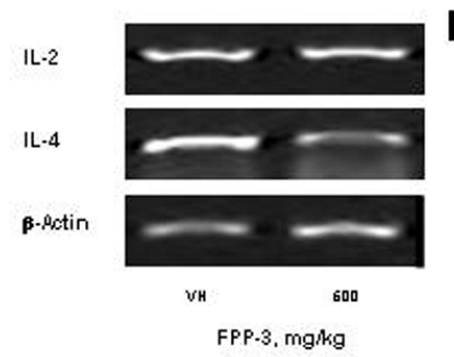

C

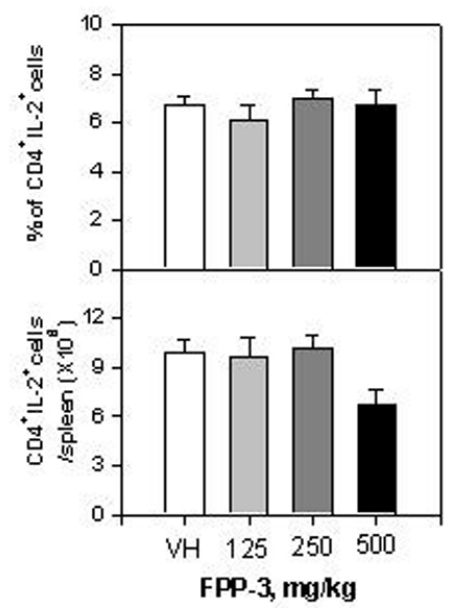

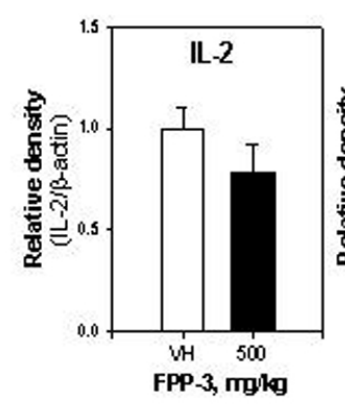

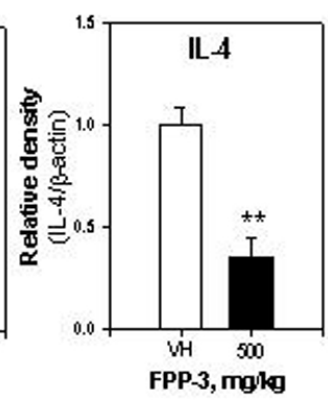

To clarify the possible mechanism(s) of FPP-3-induced immunosuppression, effects of FPP-3 on the splenic expression of cytokine mRNA and intracellular cytokine productions were investigated in this study. As shown in Fig. 6A and 6B, in RT-PCR, $500 \mathrm{mg} / \mathrm{kg}$ FPP-3 suppressed the expression of IL-4 mRNAs. The expression of IL-2 mRNA showed a weak suppression without a statistical significance. In the flow cytometry, the productions of splenic intracellular IL-4 in response to Con A were decreased in the cells isolated from mice administered with $500 \mathrm{mg} / \mathrm{kg}$ FPP-3. The numbers of CD4 ${ }^{+} \mathrm{IL}-4^{+}$cells were reduced about $42 \%$, following the administration of mice with 500 $\mathrm{mg} / \mathrm{kg}$ of FPP-3 (Fig. 6C).
Fig. 6. Effects of FPP-3 on splenic cytokine gene expressions and intracellular IL-2 and IL-4 productions in female BALB/c mice. Splenocytes isolated from FPP-3 administered mice were cultured for $24 \mathrm{hr}$ in the presence of Con A and recombinant IL-2. (A and B) RT-PCR. $\beta$-Actin was used as a control gene. (C) Flow cytometry. Experimental conditions were described in the Materials and Methods. Each bar represents the mean \pm S.E. of 5 animals. The asterisks indicate the values significantly different from the vehicle control $(\mathrm{VH})$ at $p<0.05\left(^{*}\right)$.

\section{DISCUSSION}

Investigating the immunotoxic potential of a candidate drug as a part of preclinical safety evaluation is very important. Particularly, a candidate acting on immune systems requires extensive studies on its adverse effects on immune functions. A key component of this investigation is the toxicologic profile generated through toxicity studies. The continuing efforts to develop anti-inflammatory agents from synthetic compounds led to synthesize a propenone compound FPP-3, which was demonstrated to inhibit the production of TNF- $\alpha$ and NO in the LPS-stimulated RAW264.7 macrophages (Jahng et al., 2004; Lee et al., 
2004). In our preliminary study, FPP-3 might be moderately toxic in both ICR mice and Sprague-Dawley rats, because the estimated oral median lethal dose was about $1,000 \mathrm{mg} / \mathrm{kg}$ in both sexes (unpublished data).

The immunotoxic effects of certain chemicals may result in global impacts on immunological reactivity of an organism. The immune system is an intricate complex of interrelated cellular, molecular and genetic components, which provides a defense (i.e., immune response) against foreign organisms or substances and aberrant native cells. The immune responses are expressed as autoimmunity, chemical hypersensitivity or immunosuppression (Dean et al., 1985). Traditional methods for toxicological assessment have implicated the immune system as a frequent target organ of toxic insult following exposure to certain drugs or environmental chemicals. A tiered approach, a screening battery, for characterizing potential immunotoxic compounds have been developed and validated in laboratory animals (Dean et al., 1985; Luster et al., 1988, 1992, 1993). These reports indicated that the highest associations with immunotoxicity were the T-dependent antibody response to SRBCs (78\%) and the lymphocyte subpopulation analysis (83\%) as determined by surface marker expression, and that the performances of only two or three immune tests are sufficient to predict immunotoxic compounds in rodents. Based on these literatures, some parameters of the immune function were measured in the present studies to investigate the immunotoxicological effects of FPP-3 in female BALB/c mice.

Because the AFC assay is the most sensitive indicator of the host's ability to mount an antibody response to a specific antigen (Luster et al., 1993), the splenic antibody response to SRBCs was chosen. In the present study, gross indicators of immunotoxicity, such as changes in lymphoid organ weights, were not affected following FPP-3 treatment, whereas the number of AFC was significantly reduced at the highest dose of FPP-3 (Table I and Fig. 2). These results indicated a possible immunotoxic potential of FPP-3.

Flow cytometry is a unique technology useful in the examination of effects of immunotoxic agents on target cells of the immune system. The most common application of flow cytometry to immunotoxicity testings has been in the area of cell surface immunophenotyping of subsets of lymphoid cells found in the spleen or thymus of mice. To understand the cellular target in FPP-3-induced immunotoxicity, immunophenotyping of splenic and thymic cells isolated from FPP-3 treated mice was performed. The present results indicated that the number of splenic $B$ cells was not significantly changed by FPP-3 treatment (Fig. 3). On the other hand, the numbers of total, $\mathrm{CD}^{+}$and $\mathrm{CD}^{+}{ }^{+}$ cells and macrophages in spleens were significantly reduced by $500 \mathrm{mg} / \mathrm{kg}$ FPP-3. These results suggested that the $T$ cells and macrophages in spleen might be relatively important cellular targets for FPP-3-induced immunotoxicity.

Xenobiotics-induced thymus atrophy is apparently caused by reduced proliferation rates of the immature thymocyte precursor pool leading to a reduction of the $\mathrm{CD} 4^{+} \mathrm{CD} 8^{+}$ thymocytes, which contribute approximately $80 \%$ of the thymocytes (Kremer et al., 1994). In the present study, the treatment with FPP-3 without an immunization significantly decreased in the weights and total cellularity of thymus. In addition, FPP-3 treatment resulted in the decreased percentages of immature $\mathrm{CD} 4{ }^{+} \mathrm{CD} 8{ }^{+}$thymocytes and the increased percentages of $\mathrm{CD} 4^{-} \mathrm{CD} 8^{-}$thymocytes at the highest dose (Fig. 4A). These results suggested that, in addition to the thymic hypocellularity, FPP-3 might inhibit the thymocyte maturation.

Lymphocyte stimulation with mitogens is a measure of cell-mediated and humoral immunity. Con A is well known activator of T cells and LPS is a B-cell activator (Whitehurst and Geppert, 1996). In the ex vivo lymphoproliferation assay, FPP-3 inhibited splenocyte proliferation in response to Con A, but not to LPS (Fig. 5). Inhibition of Con A-induced lymphocyte proliferation by FPP-3 suggested that FPP-3 might suppress the cellular immunity.

The effects of drugs or environmental chemicals on the immune system are produced mostly by the following potential mechanisms: (1) interaction with the activated aromatic hydrocarbon receptor (Okey et al., 1984); (2) membrane perturbation effects (Pallardy et al., 1992); (3) changed IL production (Myers et al., 1988); (4) disruption of the concentration of intracellular calcium mobilization (Davila et al., 1995); or (5) metabolic activation to reactive metabolites (Ginsberg et al., 1989).

Immune responses are regulated by various cells that are components of innate immunity and by the helper $\mathrm{T}$ (Th) cells that are components of adaptive immunity (KurtJones et al., 1987; Swain et al., 1991). Naive CD4 ${ }^{+}$(antigeninexperienced) Th0 cells may be divided into two cell subpopulations, termed as Th1 and Th2, according to differences in the activities of their secreted cytokines (Mosmann et al., 1986). Th1 cells primarily secrete IFN- $\gamma$, IL-2 and TNF- $\alpha$, which promote cellular immunity, whereas Th2 cells secrete a different set of cytokines, primarily IL-4, IL-10 and IL-13, which promote humoral immunity (Fearon and Locksley, 1996; Mosmann and Sad, 1996; Mullen et al., 2001). Th1 and Th2 cytokines both promote the growth/differentiation of their subsets and inhibit the 
growth/differentiation of the opposing subset (Seder et al., 1992).

In the study, we investigated the expression of cytokine mRNA and the ability to produce intracellular cytokines, such as IL-2 and IL-4, in Con A-treated splenocytes isolated from FPP-3 treated mice. As shown in Fig. 6A and $6 \mathrm{~B}$, FPP-3 markedly suppressed the expression of IL-4 $\mathrm{mRNA}$ at the dose of $500 \mathrm{mg} / \mathrm{kg}$ FPP-3. In case of IL-2, however, FPP-3 did not show a significant difference. In addition, the numbers of IL-2 and IL-4 producing cells were determined flow cytometrically. In vivo administration of mice with FPP-3 and a subsequent in vitro Con A-activation resulted in a significant suppression of the intracellular IL-4 production at the highest dose (Fig. 6C). These results suggested that FPP-3 would suppress the Th2 activity, and that FPP-3 could alter the function of T-cells in vivo, which coincided with a decrease in the lymphoproliferation of T-cells (Fig. 5).

Controlling the cell cycle is critical for cell growth and normal organ development. Deregulation of cell cycle progression is a signal that can initiate the apoptosis (Shi et al., 1994). In our present study, based on the flow cytometry analysis, FPP-3 did not cause any significant changes at the doses tested (data not shown).

In conclusion, our present study demonstrated that a subacute treatment with $500 \mathrm{mg} / \mathrm{kg}$ FPP-3, a dose much higher than the dose for anti-inflammatory activity, had some potential immunotoxic capabilities, including the inhibition of cytokine production and the ability to inhibit T cell proliferation.

\section{ACKNOWLEDGMENTS}

This study was supported by a grant from Yeungnam University in 2008 (208-A-235-255).

\section{REFERENCES}

Davila, D. R., Davis, D. P., Campbell, K., Cambier, J. C. Zigmond, L. A. and Burchiel, S. W. (1995). Role of alterations in $\mathrm{Ca}^{2+}$-associated signaling pathways in the immunotoxicity of polycyclic aromatic hydrocarbons. J. Toxicol. Environ. Health 45, 101-126.

Dean, J. H., Ward, E. C., Murray, M. J., Lauer, L. D. and House, R. V. (1985). Mechanisms of dimethylbenzanthraceneinduced immunotoxicity. Clin. Physiol. Biochem. 3, 98-110.

Fearon, D. T. and Locksley, R. M. (1996). The instructive role of innate immunity in the acquired immune response. Science 272, 50-53.

Ginsberg, G. L., Atherholt, T. B. and Butler, G. H. (1989). Benzo[a]pyrene-induced immunotoxicity: comparison to DNA adduct formation in vivo, in cultured splenocytes, and in microsomal systems. J. Toxicol. Environ. Health 28,
205-220.

Jahng, Y., Zhao, L. X., Moon, Y. S., Basnet, A., Kim, E. K., Chang, H. W., Ju, H. K., Jeong, T. C. and Lee, E. S. (2004). Simple aromatic compounds containing propenone moiety show considerable dual COX/5-LOX inhibitory activities. Bioorg. Med. Chem. Lett. 14, 2559-2562.

Jeon, T. W., Jin, C. H., Lee, S. K., Lee, D. W., Hyun, S. H., Kim G. H., Jun, I. H., Lee, B. M., Yum, Y. N., Kim, J. K., Kim, O. H. and Jeong, T. C. (2005). In vivo and in vitro immunosuppressive effects of benzo[k]fluoranthene in female BALB/c mice. J. Toxicol. Environ. Health A. 68, 2033-2050.

Jeon, T. W., Kim, C. H., Lee, S. K., Shin, S., Choi, J. H., Kang W., Kim, S. H., Kang, M. J., Lee, E. S. and Jeong, T. C. (2009). Hepatotoxic effects of 1-furan-2-yl-3-pyridin-2-ylpropenone, an anti-inflammatory agent, in male ICR mice. Biomol. Ther. 17, 318-324.

Kaminski, N. E., Barnes, D., Jordan, S. D. and Holsapple, M. P. (1990). The role of metabolism in carbon tetrachloridemediated immunosuppression. In vivo studies. Toxicol. Appl. Pharmacol. 102, 9-20.

Kremer, J., Gleichmann, E. and Esser, C. (1994). Thymic stroma exposed to arylhydrocarbon receptor-binding xenobiotics fails to support proliferation of early thymocytes but induces differentiation. J. Immunol. 153, 2778-2786.

Kurt-Jones, E. A., Hamberg, S., Ohara, J., Paul, W. E. and Abbas, A. K. (1987). Heterogeneity of helper/inducer T lymphocytes. I. Lymphokine production and lymphokine responsiveness. J. Exp. Med. 166, 1774-1787.

Lee, E. S., Ju, H. K., Moon, T. C., Lee, E., Jahng, Y., Lee, S. H., Son, J. K., Baek, S. H. and Chang, H.W. (2004). Inhibition of nitric oxide and tumor necrosis factor- $\alpha$ (TNF- $\alpha$ ) production by propenone compound through blockade of nuclear factor (NF)-KB activation in cultured murine macrophages. Biol. Pharm. Bull. 27, 617-620.

Luster, M. I., Munson, A. E., Thomas, P. T., Holsapple, M. P., Fenters, J. D., White, K. L. Jr., Lauer, L. D., Germolec, D. R., Rosenthal, G. J. and Dean, J. H. (1988). Development of a testing battery to assess chemical-induced immunotoxicity: National Toxicology Program's guidelines for immunotoxicity evaluation in mice. Fundam. Appl. Toxicol. 10, 2-19.

Luster, M. I., Portier, C., Pait, D. G., Rosenthal, G. J., Germolec, D. R., Corsini, E., Blaylock, B. L., Pollock, P., Kouchi, Y., Craig, W., White, K. L. Jr., Munson, A. E. and Comment, C. E. (1993). Risk assessment in immunotoxicology. II. Relationships between immune and host resistance tests. Fundam. Appl. Toxicol. 21, 71-82.

Luster, M. I., Portier, C., Pait, D. G., White, K. L. Jr., Gennings, C., Munson, A. E. and Rosenthal, G. J. (1992). Risk assessment in immunotoxicology. I. Sensitivity and predictability of immune tests. Fundam. Appl. Toxicol. 18, 200-210.

Mosmann, T. R., Cherwinski, H., Bond, M. W., Giedlin, M. A. and Coffman, R. L. (1986). Two types of murine helper T cell clone. I. Definition according to profiles of lymphokine activities and secreted proteins. J. Immunol. 136, 23482357.

Mosmann, T. R. and Sad, S. (1996). The expanding universe of T-cell subsets: Th1, Th2 and more. Immunol. Today 17, 138-146.

Mullen, A. C., High, F. A., Hutchins, A. S., Lee, H. W., Villarino, A. V., Livingston, D. M., Kung, A. L., Cereb, N., Yao, T. P., Yang, S. Y. and Reiner, S. L. (2001). Role of T-bet in 
commitment of TH1 cells before IL-12-dependent selection. Science 292, 1907-1910.

Myers, M. J., Blanton, R. H. and Bick, P. H. (1988). Inhibition of IL-2 responsiveness following exposure to benzo(a)pyren is due to alterations in accessory cell function. Int. J. Immunopharmacol. 10, 177-186.

Okey, A. B., Dube, A. W. and Vella, L. M. (1984). Binding of benzo(a)pyren and dibenz(a,h)anthracene to the Ah receptor in mouse and rat hepatic cytosols. Cancer Res. 44, 14261432.

Pallardy, M., Mishal, Z., Lebrec, H. and Bohuon, C. (1992). Immune modification due to chemical interference with transmembrane signaling: application to polycyclic aromatic hydrocarbons. Int. J. Immunopharmacol. 14, 377-382.

Seder, R. A., Paul, W. E., Davis, M. M. and de St Groth, B. F. (1992). The presence of interleukin 4 during in vitro priming determines the lymphokine-producing potential of $\mathrm{CD} 4^{+} \mathrm{T}$ cells from T cell receptor transgenic mice. J. Exp. Med. 176, 1091-1098.

Shi, L., Nishioka, W. K., Th'ng, J., Bradbury, E. M., Litchfield, D. W. and Greenberg, A. H. (1994). Premature p34cdc2 activation required for apoptosis. Science 263, 1143-1145.

Swain, S. L., Bradley, L. M., Croft, M., Tonkonogy, S., Atkins, G., Weinberg, A. D., Duncan, D. D., Hedrick, S. M., Dutton, R. W. and Huston, G. (1991). Helper T-cell subsets: phenotype, function and the role of lymphokines in regulating their development. Immunol. Rev. 123, 115-144.

Whitehurst, C. E. and Geppert, T. D. (1996). MEK1 and the extracellular signal-regulated kinases are required for the stimulation of IL-2 gene transcription in T cells. J. Immunol. 156, 1020-1029. 